\title{
LUT
}

University

\section{Treatment of mining wastewater polluted with cyanide by coagulation processes: a mechanistic study}

Mamelkina Maria A., Herraiz-Carboné Miguel, Cotillas Salvador, Lacasa Engracia, Sáez Cristina, Tuunila Ritva, Sillanpää Mika, Häkkinen Antti, Rodrigo Manuel A.

This is a Author's accepted manuscript (AAM) version of a publication published by Elsevier

in Separation and Purification Technology

DOI: $\quad 10.1016 / j . s e p p u r .2019 .116345$

Copyright of the original publication: () 2019 Elsevier B.V.

Please cite the publication as follows:

Mamelkina, M.A., Herraiz-Carboné, M., Cotillas, S., Lacasa, E., Sáez, C., Tuunila, R., Sillanpää, M., Häkkinen, A. \& Rodrigo, M.A. 2020, "Treatment of mining wastewater polluted with cyanide by coagulation processes: A mechanistic study", Separation and Purification Technology, vol. 237, pp. 116345. DOI:10.1016/j.seppur.2019.116345

This is a parallel published version of an original publication. This version can differ from the original published article. 


\section{Treatment of mining wastewater polluted with cyanide}

3 Maria A. Mamelkina ${ }^{1}$, Miguel Herraiz-Carboné ${ }^{2}$, Salvador Cotillas $^{2}$, Engracia Lacasa ${ }^{2}$,

4 Cristina Sáez ${ }^{3}$, Ritva Tuunila ${ }^{1}$, Mika Sillanpää ${ }^{1}$, Antti Häkkinen $^{1}$, Manuel A. Rodrigo ${ }^{3 *}$

$7 \quad{ }^{2}$ Department of Chemical Engineering, School of Industrial Engineering, University of Castilla-La Mancha, 02071 Albacete, Spain

${ }^{3}$ Department of Chemical Engineering, Faculty of Chemical Sciences and Technologies, University of Castilla-La Mancha, 13005 Ciudad Real, Spain

\section{Abstract}

13 In this work, coagulation and electrocoagulation for the removal of cyanide ions

14 contained in synthetic mining wastewater were evaluated paying particular attention to 15 the elucidation of the coagulation mechanisms. Iron and aluminum salts with 16 concentrations ranging from 0.01 to $10000 \mathrm{mg} \mathrm{dm}^{-3}$ metal were used in chemical

17 coagulation. Experimental data were properly fitted to Freundlich isotherm to elucidate

18 that the main mechanism to remove cyanide during chemical coagulation was adsorption

19 onto coagulant flocs although a maximum cyanide removal percentage of only $25 \%$ was

20 attained. Then, electrochemical coagulation with iron and aluminum electrodes was

21 evaluated at 1,10 and $100 \mathrm{~A} \mathrm{~m}^{-2}$, obtaining completely different results. Iron electrochemical coagulation leads to the complete cyanide removal regardless of the 
current density applied, although the TOC removal was much lower than expected. On

24 the contrary, only $60 \%$ of cyanide removal was reached by aluminum electrochemical coagulation and its efficiency was found to be highly dependent on the current density applied. Furthermore, no cyanate or hazardous inorganic chlorine species were detected

27 during both electrocoagulation processes. However, chloride was oxidized to 28 hypochlorite and then, it reacted with ammonium ions (contained in mining wastewater 29 or produced by chemical reduction of nitrate by aluminum) to form chloramines. A 30 proposal of coagulation mechanisms during the electrochemical process that explains 31 experimental results was developed which involved the formation of iron-cyanide 32 complexes, charge neutralization, adsorption on a superficially charged metal precipitate 33 and/or enmeshment into a sweep metal floc.

Keywords: cyanide; mining wastewater; chemical coagulation; electrochemical coagulation; coagulation mechanisms

\section{Highlights}

- Cyanide is poorly removed by adsorption onto metal flocs in chemical coagulation.

41 - Iron electrochemical coagulation leads to a complete cyanide removal.

42 - Formation of soluble iron cyanide complexes allows reducing solution toxicity.

43 - Cyanide solubility decreases by charge neutralization with soluble $\mathrm{Al}(\mathrm{OH})_{3}$.

$44 \quad-\quad$ Null detection of cyanate or hazardous inorganic chlorine species. 
$46 *$ Corresponding author e-mail: manuel.rodrigo@uclm.es. Tel.: +34-926-29-53-00 Ext.

47 3411; fax: +34-926-29-52-56

48 


\section{Introduction}

50 Free cyanide may be contained in industrial wastewater such as mining, metallurgical, 51 petrochemical or coking wastewater [1-4]. About $13 \%$ of the 1.1 million metric tons of hydrogen cyanide produced annually worldwide is consumed by mining and metallurgical processes [5]. In mining processes, cyanide solutions are primarily used for

54 the extraction of gold and silver from crushed ores. In addition, also they may be used to recover other metals such as copper, lead and zinc. The $\mathrm{pH}$ of cyanide solutions is a key

56 parameter because free cyanide can be in the form of cyanide anion or volatile hydrocyanic acid, this last form being the predominant species for $\mathrm{pH}$ values below 8.5. Cyanide is considered a very toxic substance, because it can inhibit oxygen transfer to the cells due to its ability to bind iron in the blood by forming complexes and then, it can

60 cause suffocation in animals and humans. The oral cyanide dose that is lethal to $50 \%$ of 61 the exposed population ranges between 1 and $3 \mathrm{mg} / \mathrm{kg}$ of body weight.

62 The cyanide removal from industrial wastewater by conventional technologies has been widely reported during the last decade. Thus, cyanide may be degraded to ammonia by microorganisms under aerobic conditions [1] or it may be oxidized to less toxic cyanate by strong oxidizing agents such as hydrogen peroxide, hypochlorite and ozone [6]. In

66 addition, it may be adsorbed on clays, feldspars and organic carbon, react with sulfur to

67 form the seven-times less toxic thiocyanate and it may also strongly bind with various metals such as $\mathrm{Fe}, \mathrm{Cu}, \mathrm{Ni}, \mathrm{Mn}, \mathrm{Pb}, \mathrm{Zn}, \mathrm{Cd}, \mathrm{Sn}$ or $\mathrm{Ag}$ to generate soluble and/or insoluble cyanide-metal complexes which are mostly non-reactive compounds [2, 3, 7-10].

70 Electrochemical technologies have recently emerged for industrial applications thanks to

71 their simple equipment and easy automation in different environments and scales [11-16].

72 Furthermore, these technologies can be considered as environmentally friendly because 
no addition of chemicals is needed and they can also be easily powered with green energy sources such as solar panels, windmills or fuel cells [17-20]. Among others,

electrochemical oxidation, electro-Fenton and electrochemical coagulation have been reported to remove cyanide from industrial wastewaters. Both electrochemical oxidation and electro-Fenton leads to the oxidation of cyanide to cyanate and then, cyanate is mineralized to carbon dioxide and nitrogen. At this point, electrochemical oxidation attained around $90 \%$ of cyanide removal by using several anode materials such as mixed metal oxides, platinum, $\mathrm{PbO}_{2}$ or boron doped diamond [21-23]. Likewise, electro-Fenton with reticulated vitreous carbon as cathode material reached over $90 \%$ of cyanide oxidation to cyanate by electrochemically generated hydrogen peroxide [24]. On the contrary, electrochemical coagulation is mainly based on the release of coagulants from a sacrificial anode. These species reduce the solubility of free cyanide in solution by different mechanisms. In literature, efficiencies over $90 \%$ for the removal of cyanides were reported by using electrochemical coagulation with iron electrodes, although no indepth studies on removal mechanisms were found [25-27].

In this context, this paper mainly focuses on the development of coagulation mechanisms both in chemical and electrochemical coagulation processes to remove $100 \mathrm{mg} \mathrm{dm}^{-3}$ of cyanide in synthetic mining wastewater at alkaline pHs. To do this, standard jar test experiments were carried out by using iron and aluminum salts. Likewise, iron and aluminum electrodes inserted in a flow-by electrochemical reactor were tested under several current density values. Finally, the chemical reactivity of organic and inorganic species contained in solution was studied in order to rule out the formation of hazardous species. 


\section{Material and methods}

98

99

100

101

102

103

104

105

106 Chemical coagulation experiments were developed by using the standard Jar-test

107 technique. Each flask was filled with a volume of $500 \mathrm{~mL}$ of mining wastewater

108 intensified with $100 \mathrm{mg} \mathrm{CN}^{-} \mathrm{dm}^{-3}$. Then the selected iron or aluminum chloride

\subsection{Chemicals}

Sodium cyanide and mining wastewater compounds [12] were of analytical grade and purchased from Panreac Química SLU. Chemicals to analyze cyanide were purchased from Merck and other chemicals used in several analyses were purchased from Sigma Aldrich, and each one was also analytical grade. Double deionized water of Millipore Milli-Q system with a resistivity of $18.2 \mathrm{M} \Omega \mathrm{cm}$ at $25^{\circ} \mathrm{C}$ was used to prepare each solution.

\subsection{Experimental procedures}

concentration was added, followed by the dosing of $\mathrm{NaOH}$ solution used for $\mathrm{pH}$ adjustment to a value of 12 . After that, the mixture underwent 3 min rapid mixing and 12 min slow mixing. Then, after settling for $30 \mathrm{~min}$, the supernatant liquid was filtered through a $0.20 \mu \mathrm{m}$ filter and then, cyanide concentration was measured.

Electrochemical coagulation experiments were carried out in a single compartment flow cell working under batch operation mode [28, 29]. The electrodes placed in the electrochemical cell were made of iron and aluminum, and both anode and cathode materials were the same at each experiment. The electrode dimensions were $10 \mathrm{~cm}$ x 10 $\mathrm{cm}^{2}$ and the net spacing between electrodes was $0.9 \mathrm{~cm}$. The electric current was applied by using a Delta Electronika ES030-10 power supply characterized by the ranges 0-10 A and $0-30 \mathrm{~V}$, and the current flowing through the cell was measured with a Keithley 2000 
120 digital multimeter. Each experiment was carried out under galvanostatic conditions and

121 the current densities applied were 1,10 and $100 \mathrm{~A} \mathrm{~m}^{-2}$. A volume of $2.0 \mathrm{~L}$ of mining wastewater intensified with $100 \mathrm{mg} \mathrm{CN}^{-} \mathrm{dm}^{-3}$ (at initial $\mathrm{pH}$ of 12) were introduced into a

123 glass tank and then, recirculated through the electrochemical cell using a peristaltic pump.

124 Samples of $75 \mathrm{~mL}$ were collected each time and after settling time of $30 \mathrm{~min}$, the 125 supernatant liquid was filtered through a $0.20 \mu \mathrm{m}$ filter for the determination of cyanide 126 and other inorganic ions. TOC measurements were carried out without filtration. The 127 chemical coagulation tests were performed during 15 minutes whereas electrochemical 128 coagulation experiments were carried out during 540 minutes each one.

129 The chemical composition of the synthetic mining wastewater used has been previously 130 reported elsewhere [12].

\section{$131 \quad$ 2.3. Analytical procedures}

132 Cyanide concentrations were determined by silver nitrate titration method, which was 133 initially introduced by Ryan and Culshaw [30]. The silver nitrate $\left(\mathrm{AgNO}_{3}\right)$ titration bases 134 on the reactions produced by this salt in a cyanide media, where soluble silver cyanide complex $\left(\mathrm{Ag}(\mathrm{CN})_{2}^{-}\right)$is firstly formed (Eq. 1), after which, the excess $\mathrm{Ag}^{+}$ions complex

136 with rhodanine turning the color from a yellow to a pale pink. Further addition of $\mathrm{AgNO}_{3}$

137 yields solid argentocyanide (AgCN) (Eq. 2). In this study, a modified standard method 138 was used. $\mathrm{AgNO}_{3}$ stock solution was further diluted to yield 0.00125 and $0.000125 \mathrm{M}$ $139 \mathrm{AgNO}_{3}$ solutions for the titrations. Stronger $\mathrm{AgNO}_{3}$ solution was used for samples 140 containing more than $10 \mathrm{mg} \mathrm{dm}^{-3}$ of cyanide whereas more dilute was used for samples

141 containing 1-10 $\mathrm{mg} \mathrm{dm}^{-3}$ of cyanide. The indicator solution was prepared by dissolving $1420.03 \mathrm{~g}$ 5-(4-Dimethylaminobenzylidene)-rhodanine in $0.1 \mathrm{dm}^{3}$ acetone and stored in a 143 dark bottle. The titrations were carried out with $0.005 \mathrm{dm}^{3}$ of cyanide solution to which 
144 four drops of rhodamine indicator solution were added, after which the sample was

145 titrated to a color change. Finally, the concentration of $\mathrm{CN}^{-}$was calculated using Equation

146 (3), where $\mathrm{M}$ is the molar mass $\left(\mathrm{g} \mathrm{mol}^{-1}\right), \mathrm{V}$ is volume $\left(10^{-3} \mathrm{dm}^{3}\right)$, and factor of reagent is

1470.012255 for $0.00125 \mathrm{M} \mathrm{AgNO}_{3}$ solution and 0.0012255 for $0.000125 \mathrm{M} \mathrm{AgNO}_{3}$

148 solution.

$$
\mathrm{Ag}^{+}+2 \mathrm{CN}^{-} \rightarrow \mathrm{Ag}(\mathrm{CN})_{2}^{-}
$$

$$
\mathrm{Ag}^{+}+\mathrm{Ag}(\mathrm{CN})_{2}^{-} \rightarrow 2 \mathrm{AgCN}
$$

In addition, ion chromatography by using a Metrohm 930 Compact IC Flex coupled to a

Supp 7 located in an oven at $45{ }^{\circ} \mathrm{C}$ with a mobile phase of $85: 15 \mathrm{v} / \mathrm{v} 3.6 \mathrm{mM}$

$\mathrm{Na}_{2} \mathrm{CO}_{3}$ /acetone were used to analyze anions whereas cations were analyzed by using the column Metrosep C6 250 at $30{ }^{\circ} \mathrm{C}$ with a mobile phase of $1.7 \mathrm{mM} \mathrm{HNO}_{3}$ and $1.7 \mathrm{mM}$ 2,6-pyridinedicarboxylic acid. The flow rates of mobile phases were 0.8 and $0.9 \mathrm{~cm}^{3} \mathrm{~min}^{-}$

$158{ }^{1}$ to determine anions and cations, respectively. In both cases, $20 \mu \mathrm{L}$ was the volume 159 injection of each sample.

160 The total iron or aluminum concentration was measured off-line using an inductively 161 coupled plasma Liberty Sequential Varian system according to the standard methods. The $162 \mathrm{pH}$ and conductivity were simultaneously measured using a Sension+ MM150 Portable 163 Multi-Parameter Meter from HACH. The Total Organic Carbon (TOC) was determined 164 using a Shimadzu TOC-VCPH analyzer and the theoretical TOC was calculated 165 according to Equation 4 where $\left[\mathrm{CN}^{-}\right]$is referred to free cyanide that remains in solution, $166 \mathrm{AW}_{\mathrm{C}}$ is the atomic weight of carbon $\left(12 \mathrm{~g} \mathrm{~mol}^{-1}\right)$ and $\mathrm{MW}_{\mathrm{CN}}$ is the molecular weight of 
167 cyanide $\left(26 \mathrm{~g} \mathrm{~mol}^{-1}\right)$. In addition, hypochlorite was analyzed by titration with $0.001 \mathrm{M}$ $168 \mathrm{As}_{2} \mathrm{O}_{3}$ in $2 \mathrm{M} \mathrm{NaOH}[31,32]$.

$$
\mathrm{TOC}_{\mathrm{th}}=\left[\mathrm{CN}^{-}\right] \cdot\left(\mathrm{AW}_{\mathrm{C}} / \mathrm{MW}_{\mathrm{CN}-}\right)
$$

170 Finally, the sludge generated during both conventional and electrochemical coagulation

171 was characterized by X-Ray Diffraction (XRD) analysis using a Philips PW-1710

172 instrument with $\mathrm{Ni}$-filtered $\mathrm{Cu} \mathrm{k} \alpha$ radiation $(\lambda: 1.5404 \AA)$. Samples were scanned at a rate 173 of $0.02^{\circ}$ step $^{-1}$ within the range $10^{\circ} \leq 2 \theta \leq 90^{\circ}$ and the diffractograms obtained were 174 compared with the JCPDS-ICDD references.

\section{Results and discussion}

177 Figure 1 shows the percentage of cyanide removed during the chemical coagulation of $178100 \mathrm{mg} \mathrm{dm}^{-3}$ of cyanide in mining wastewater. Every test was developed at $\mathrm{pH} 12$ to 179 ensure the stability of cyanide ion in aqueous solution avoiding the release of HCN. Thus, 180 after the addition of the coagulant with the corresponding decrease in the $\mathrm{pH}$, this

181 parameter was rapidly modified up to 12.0 . The coagulants tested were inorganic salts of 182 iron $\left(\mathrm{FeCl}_{3}\right)$ and aluminum $\left(\mathrm{AlCl}_{3}\right)$ within the wide range $0.01-10000 \mathrm{mg} \mathrm{dm}^{-3}$. Ferric

183 iron $\left(\mathrm{Fe}^{3+}\right)$ was selected as iron salt because the $\mathrm{pH}$ conditions used leads to a rapid 184 oxidation of ferrous iron $\left(\mathrm{Fe}^{2+}\right)$ to ferric form in water [33]. 


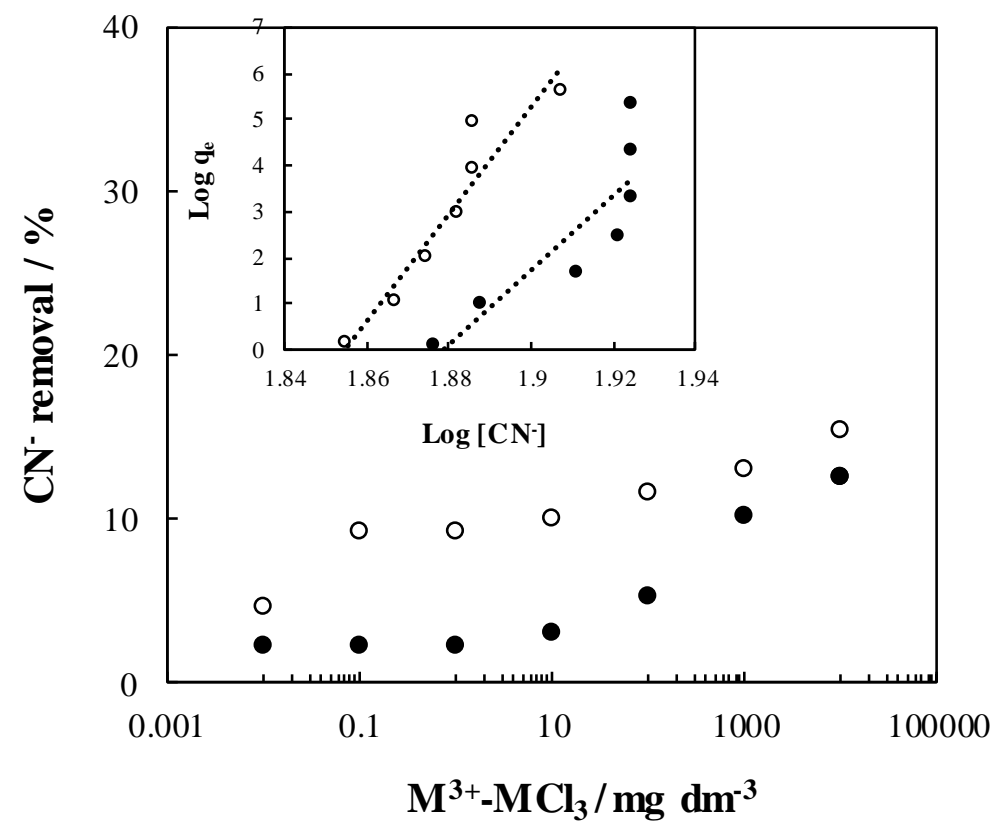

187 Figure 1. Cyanide removal percentage as a function of coagulant dosages during 188 chemical coagulation of synthetic mining wastewater intensified with $100 \mathrm{mg} \mathrm{CN}^{-} \mathrm{dm}^{-3}$ 189 at $\mathrm{pH}$ of 12. Inorganic coagulants: $\mathrm{Fe}^{3+}-\mathrm{FeCl}_{3}$ (full symbols), $\mathrm{Al}^{3+}-\mathrm{AlCl}_{3}$ (empty 190 symbols). The inset shows data fitted to Freundlich isotherm.

192 As it can be seen, both reagents can help to remove cyanide, although the efficiency is 193 not very high and cyanide removal percentages during chemical coagulation are always 194 below $15 \%$, even for the highest coagulant dosage of $10000 \mathrm{mg} \mathrm{dm}^{-3}$. This last value 195 generates a large amount of sludge in the final effluent and, for this reason, no higher 196 coagulant doses were used. In addition, the percentage of cyanide removed is higher with 197 the aluminum than with the iron coagulant dosages.

198 Initially, adsorption of the cyanide onto the growing hydroxide precipitates is the 199 expected primary mechanism to explain the removal of this pollutant. To confirm this 200 and, thus, to elucidate the possible mechanisms which control the removal of cyanide in 
mining wastewater by using chemical coagulation processes, experimental data were

202 fitted to Freundlich isotherm (Eq. 5) as shown in the inset of Figure 1. The Freundlich

203 isotherm is an adsorption curve which relates the equilibrium concentration of a solute

204 adsorbed onto the surface of a solid through chemisorption, physisorption or both ( $q, m g$

$205 C \mathrm{~N}^{-}$adsorbed / $\left.\mathrm{g} M-\mathrm{MCl}_{3}\right)$ with the concentration of the solute in the solution $\left(C \mathrm{~N}^{-}, \mathrm{mg}\right.$

$206 d m^{-3}$ ). The models obtained for iron and aluminum adsorbents are shown in Equations 6

207 and 7, respectively. As observed, fitting of the experimental data to the model is not

208 perfect and suggests that, in addition to adsorption, other processes must be contributing

209 to the removal of cyanide. Thus, experimental data are observed to fit the Freundlich

210 isotherm during aluminum chemical coagulation with a regression coefficient of 0.9047

211 whereas for chemical coagulation with iron, data fit the Freundlich isotherm with a lower

212 regression coefficient of 0.7585 . This fact supports the hypothesis made regarding that

213 cyanide in mining wastewater is removed by adsorption onto aluminum or iron flocs

214 formed during the chemical coagulation process. However, the extremely low values

215 obtained for Freundlich's constant $\left(K_{F}\right)$ indicates a low adsorption capacity from

216 adsorbents added during chemical coagulation to remove cyanide from mining

217 wastewater in comparison with other $K_{F}$ values reported in literature [34-37] and the co-

218 existence of other processes, most probably complexation processes.

$$
\mathrm{q}_{\mathrm{e}}=\mathrm{K}_{\mathrm{F}} \cdot \mathrm{C}_{\mathrm{e}}^{1 / \mathrm{n}}
$$

$$
\mathrm{q}=4 \cdot 10^{-154} \cdot\left[\mathrm{CN}^{-}\right]^{81.67}
$$

222 Coagulation and electrocoagulation technologies differ significantly in the way in which the coagulants are added to the wastewater and it is reported that this type of addition of 
224 inorganic coagulants in solution may significantly affect the pollutant removal efficiency

225 of the coagulation process $[38,39]$. The chemical coagulation process involves the

226 addition of inorganic salts, mainly iron or aluminum salts, as coagulants which alters the

227 physicochemical composition of the solution by increasing its conductivity. On the

228 contrary, the electrochemical coagulation process involves the in-situ generation of

229 coagulants through the electro-dissolution of a sacrificial anode, which is usually made

230 of iron or aluminum. At this point, Figure 2 shows the cyanide removal from mining

231 wastewater during electrochemical coagulation with iron (Figure 2a) and aluminum

232 (Figure 2b) electrodes. The electrochemical coagulation processes were developed within

233 the range of current densities $1-100 \mathrm{~A} \mathrm{~m}^{-2}$ and no passivation phenomena were observed

234 for all the tests carried out with both electrode materials. 

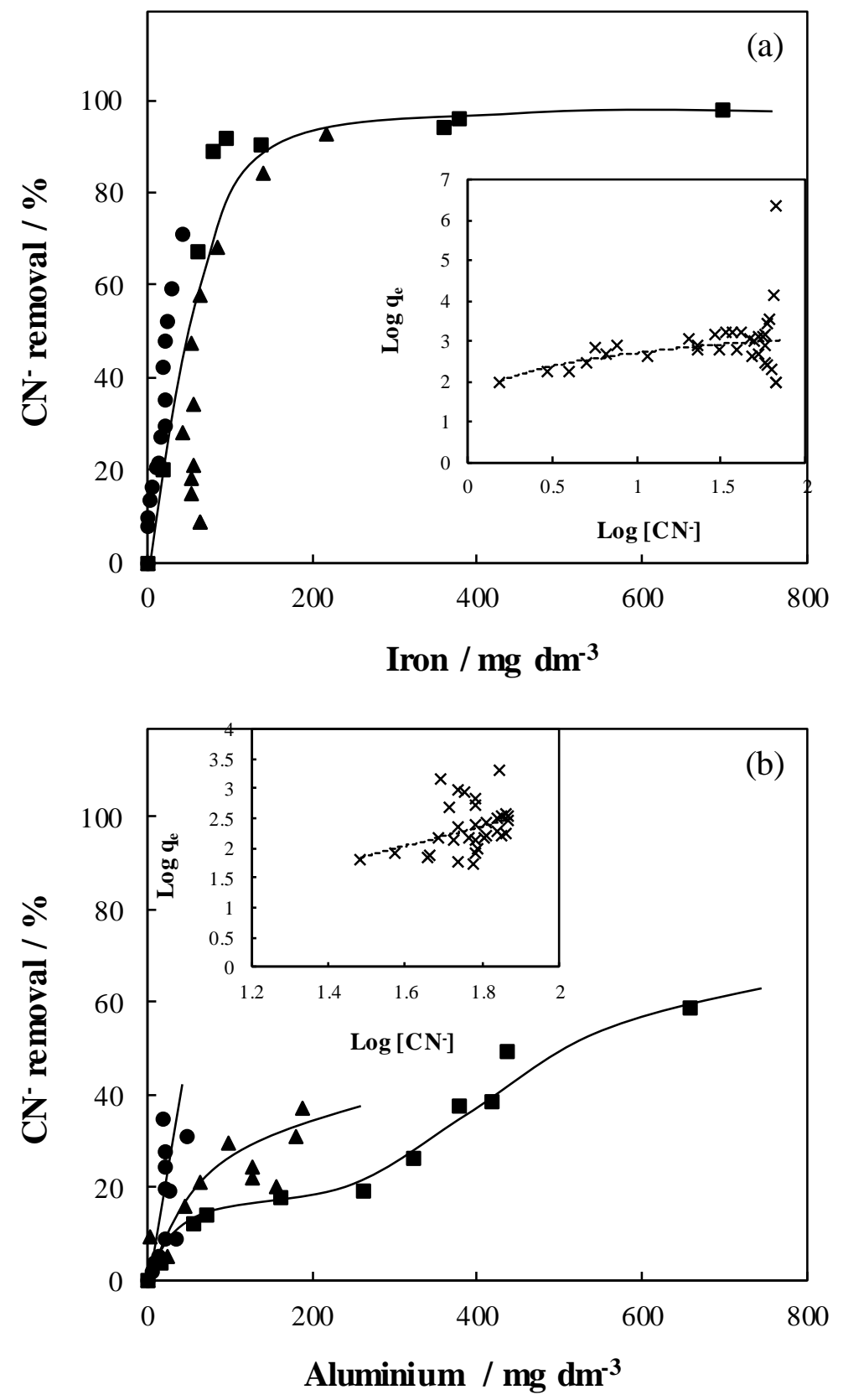

237 Figure 2. Cyanide removal percentage as a function of electrogenerated coagulant 238 concentration during electrochemical coagulation of synthetic mining wastewater 239 intensified with $100 \mathrm{mg} \mathrm{CN}^{-} \mathrm{dm}^{-3}$ at initial $\mathrm{pH}$ of 12 . Anode/Cathode: $\mathrm{Fe} / \mathrm{Fe}$ (a), $\mathrm{Al} / \mathrm{Al}$

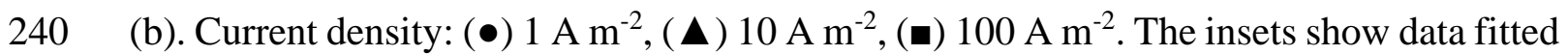
241 to Freundlich isotherm. 
243 Surprisingly, cyanide is completely removed from mining wastewater during

244 electrochemical coagulation at initial $\mathrm{pH}$ of 12 by using iron electrodes with almost

245 negligible influence of current density applied. However, less than $60 \%$ of cyanide

246 removal is attained for electrochemical coagulation with aluminum electrodes. In

247 addition, a significant influence of the current density on cyanide removal is clearly

248 observed with this electrode. Then, $50 \%$ of cyanide removal is reached for $50 \mathrm{mg} \mathrm{dm}^{-3}$ of

249 iron, regardless the current density applied whereas 40, 15 and 5\% of cyanide removal is

250 achieved for the same dosage of aluminum during electrochemical coagulation at 1,10

251 and $100 \mathrm{~A} \mathrm{~m}^{-2}$, respectively. This fact means that iron is much more efficient than

252 aluminum for the removal of cyanide from mining wastewater when coagulants are dosed

253 by a sacrificial anode in the electrochemical coagulation processes, regardless of the

254 current density applied, opposite than the behavior observed during the chemical

255 coagulation processes. Furthermore, the higher current density applied, the lower is the

256 cyanide removal efficiency observed during aluminum electrochemical coagulation

257 processes.

258 For comparison purposes, and in order to know more about mechanisms, data obtained

259 during the iron and aluminum electrochemical coagulation processes were also fitted to a

260 Freundlich isotherm and plots are shown in the insets of Figure $2 a$ and $2 b$, respectively.

261 In both cases, the theoretical Freundlich isotherm line does not fit well experimental data

262 as a high dispersion of experimental points can be observed with regression coefficients

263 of only 0.1269 for iron (Eq. 8) and 0.1158 for aluminum (Eq. 9). This fact confirms that

264 the main mechanism to remove cyanide from mining wastewater during electrochemical

265 coagulation is not adsorption onto iron or aluminum flocs as hypothesized during 266 chemical coagulation. 
267 Here, it is noteworthy to point out that iron or aluminum speciation significantly depends

268 on the dosage form, the $\mathrm{pH}$ of the solution and their concentration [38]. In this context, it

269 is important to bear in mind that the $\mathrm{pH}$ was fixed at 12 for the chemical coagulation using

270 the standard jar test experiments and corrected after the addition of the coagulants to reach

271 again the same $\mathrm{pH}$ value (because the salts behave as Lewis acids) whereas for the

272 electrochemical tests, $\mathrm{pH}$ was initially fixed at 12 and then, monitored along

273 electrochemical coagulation processes without further changes, as in this case the net

274 reagent dosed is iron or aluminum hydroxide, which does not behave as a Lewis acid.

275 Thus, Figure 3 shows the evolution of coagulant-pH in the speciation maps for the

276 removal of cyanide in mining wastewater during the iron (Figure 3a) and aluminum

277 (Figure 3b) electrochemical coagulation processes within the range of current densities

278 from 1 to $100 \mathrm{~A} \mathrm{~m}^{-2}$, and during chemical coagulation tests with iron (Figure $3 \mathrm{c}$ ) and

279 aluminum (Figure 3d) salts. Initial $\mathrm{pH}$ was adjusted before start the experiments to a value

280 of 12 . In the case of chemical tests, this adjustment was carried out again after adding the

281 coagulant since aluminium and iron salts decrease the solution $\mathrm{pH}$.

$$
\mathrm{q}=121.43 \cdot\left[\mathrm{CN}^{-}\right]^{0.59}
$$



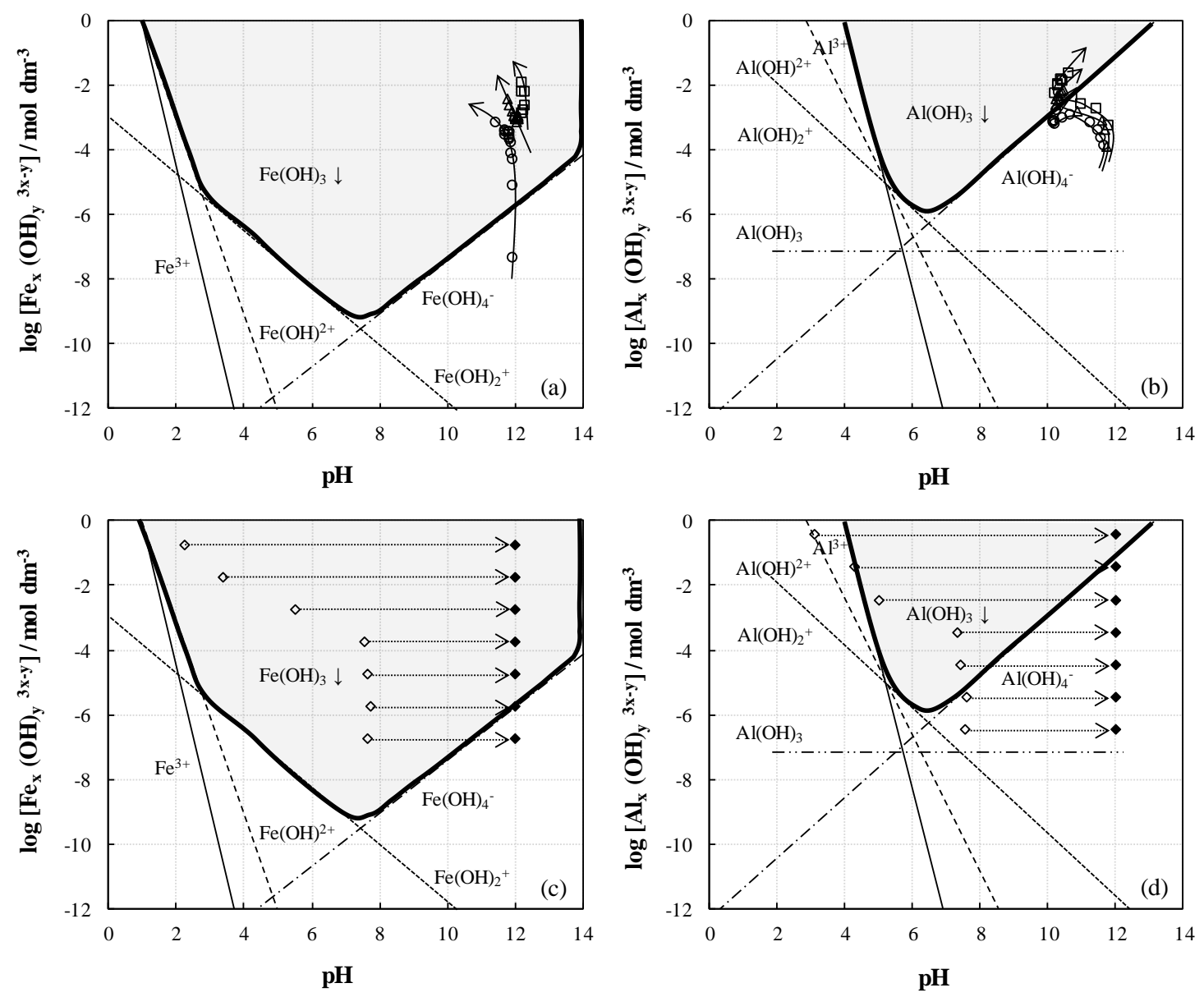

285 Figure 3. Coagulant-pH evolution during chemical and electrochemical coagulation of 286 synthetic mining wastewater intensified with $100 \mathrm{mg} \mathrm{CN}^{-} \mathrm{dm}^{-3}$. Electrochemical 287 coagulation: anode/cathode: $\mathrm{Fe} / \mathrm{Fe}(\mathrm{a}), \mathrm{Al} / \mathrm{Al}(\mathrm{b})$; current density: (०) $1 \mathrm{~A} \mathrm{~m}^{-2},(\Delta) 10 \mathrm{~A}$ $288 \mathrm{~m}^{-2}$, (口) $100 \mathrm{~A} \mathrm{~m}^{-2}$. Chemical coagulation: coagulant salts: $\mathrm{FeCl}_{3}$ (c), $\mathrm{AlCl}_{3}$ (d); pH correction: initial $\mathrm{pH}(\diamond)$, corrected $\mathrm{pH}(\diamond)$. Arrows indicate the trends in $\mathrm{pH}$ during the process

292 The $\mathrm{pH}$ is observed to be maintained in values close to 12 during iron electrochemical 293 coagulation regardless the current density applied and under these conditions, the 294 electrodissolved $\mathrm{Fe}^{+2}$ may be quickly oxidized and hydrolyzed to iron precipitate $\mathrm{Fe}(\mathrm{OH})_{3}$ 295 as the main ionic monomeric species in solution. Opposite, $\mathrm{pH}$ is observed to decrease 
down to 10 throughout aluminum electrochemical coagulation and this decrease is faster

297 at lower current density values. Here, two different phases can be distinguished depending on $\mathrm{pH}$ evolution. Firstly, the soluble ionic monomeric species $\mathrm{Al}(\mathrm{OH})_{4}{ }^{-}$and $\mathrm{Al}(\mathrm{OH})_{3}$ are

299 the main aluminum species in solution when $\mathrm{pH}$ decreases from 12 to 10 and secondly,

300 the aluminum precipitate $\mathrm{Al}(\mathrm{OH})_{3}$ is the dominant aluminum species when $\mathrm{pH}$ is

301 maintained constant in a value of 10 . Then, different $\mathrm{pH}$ behavior is observed depending

302 on coagulation process as $\mathrm{pH}$ was maintained in a constant value of 12 during chemical coagulation at standard jar test experiments and, as a consequence, different iron or aluminum species are present in solution depending on coagulation process. Regarding

305 the chemical coagulation tests, it can be seen how the initial addition of the coagulant 306 acidifies the mining wastewater from the initial value of 12 to a value which decreases

307 with the increasing coagulant dose and how during the tests, this acidification is compensated with the addition of sodium hydroxide to reach $\mathrm{pH} 12$ again, leading to a very different expected speciation, which is much less efficient than that obtained by the

310 electrochemical process naturally. In addition, because of the expected high solubility of

311 aluminum hydroxide at $\mathrm{pH} 12$, the presence of other precipitates should be expected,

312 which protects the insoluble product formed during the initial addition of the coagulant.

313 At this point, it is worth to take in mind that the bonding properties of cyanide ion make 314 it a very strong-field ligand for several transition metals [40]. Among others, cyanide ion

315 is capable of forming hexacyanides with titanium, vanadium, chrome, manganese, iron 316 or cobalt, tetracyanides with nickel, palladium or platinum and dicyanides with copper,

317 silver or gold. In this way, Figure 4 shows the TOC removal percentage as a function of 318 iron (Figure 4a) and aluminum (Figure 4b) electrogenerated concentrations for the 319 electrochemical coagulation treatment of synthetic mining wastewater intensified with $320100 \mathrm{mg} \mathrm{dm}^{-3}$ of free cyanide, in order to study the possible formation of soluble cyano 
321 metal complexes. TOC present in synthetic mining wastewater comes from the carbon in

322 cyanide ion. In addition, the theoretical TOC removal calculated from Eq. 4 has also been 323 plotted here.
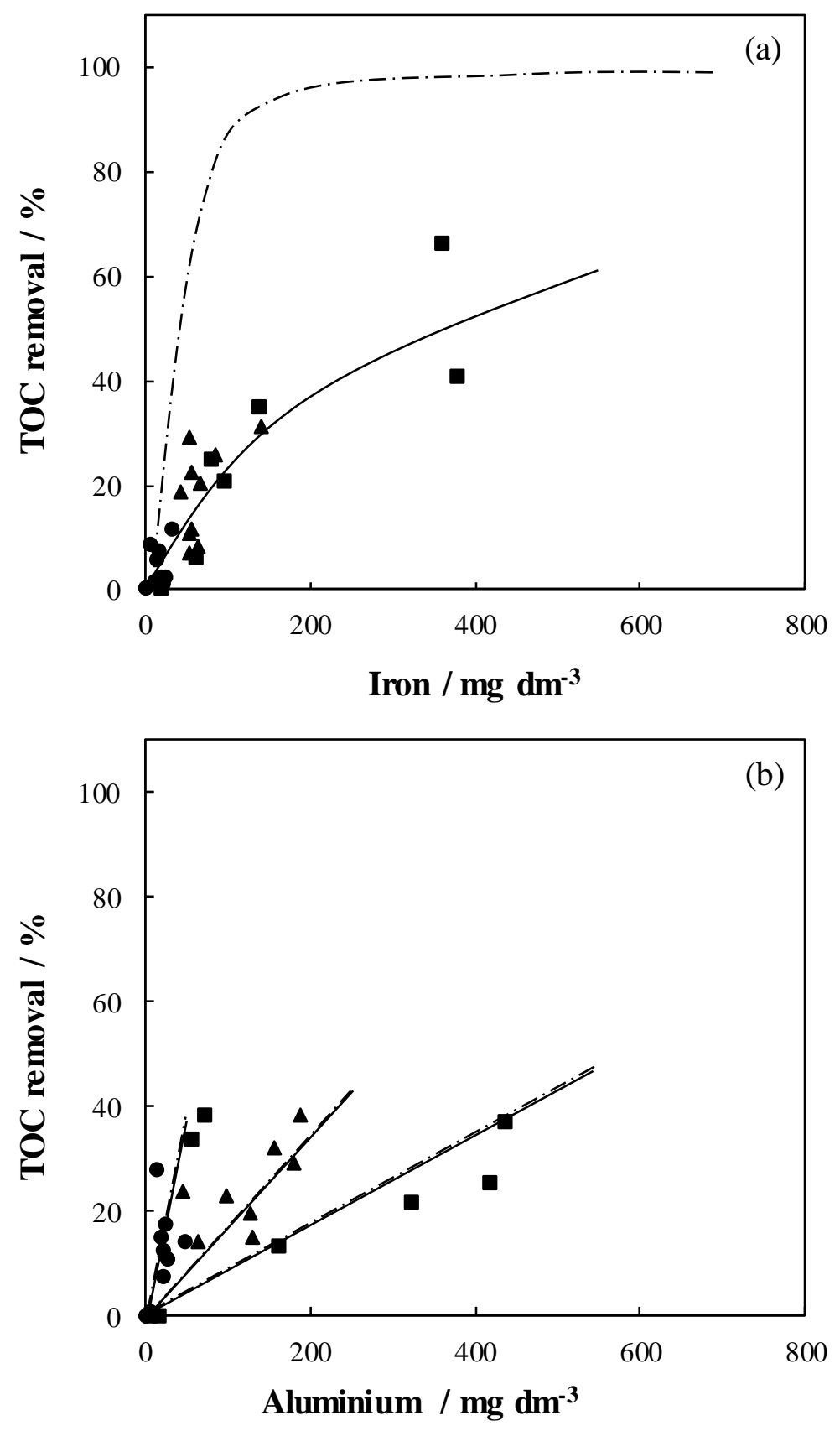

325 Figure 4. TOC removal percentage as a function of electrogenerated coagulant 326 concentration during electrochemical coagulation of synthetic mining wastewater 327 intensified with $100 \mathrm{mg} \mathrm{CN}^{-} \mathrm{dm}^{-3}$. Anode/Cathode: $\mathrm{Fe} / \mathrm{Fe}(\mathrm{a}), \mathrm{Al} / \mathrm{Al}$ (b). Current density: 
(•) $1 \mathrm{~A} \mathrm{~m}^{-2},(\boldsymbol{\Delta}) 10 \mathrm{~A} \mathrm{~m}^{-2},(\boldsymbol{\bullet}) 100 \mathrm{~A} \mathrm{~m}^{-2}$. Dashdotted lines represent theoretical TOC removal according to experimental data.

330

331 Regarding the evolution of TOC removal percentage during the iron electrochemical coagulation, the result obtained is much lower than the expected value and no influence of the current density is observed. At the end of each experiment, the experimental TOC

334 removal percentage is expected to be up to $100 \%$ vs. less than $60 \%$ of TOC removal 335 percentage monitored. This fact suggests that free cyanide is not totally removed from 336 solution and it could still remain as soluble cyano iron complexes in wastewater. 337 According to literature, the complexation reactions between iron (II) and free cyanide 338 ions may be described by Eqs. (10-12) [41]. Iron (II) is firstly electrodissolved from an 339 iron electrode during electrochemical coagulation process and then, iron (II) reacts with 340 free cyanide to form soluble ferrocyanide complex $\left(\mathrm{Fe}(\mathrm{CN}) 6^{4-}\right)$ as shown in Equation (10).

341 When the amount of ferrous ions increases throughout experimental time, $\mathrm{Fe}(\mathrm{CN})_{6}{ }^{4-}$ may 342 be immobilized as an insoluble ferrocyanide $\left(\mathrm{Fe}_{2}{ }^{\mathrm{II}} \mathrm{Fe}^{\mathrm{II}}(\mathrm{CN})_{6}\right)$ which can be quickly 343 oxidized to form insoluble ferric ferrocyanide $\left(\mathrm{Fe}_{4}{ }^{\mathrm{III}}\left[\mathrm{Fe}^{\mathrm{II}}(\mathrm{CN})_{6}\right]_{3}\right)$. However, the presence 344 of soluble $\mathrm{Fe}(\mathrm{CN})_{6}{ }^{4-}$ in solution is much less toxic than free cyanide and its formation is 345 essentially nontoxic except under UV-irradiating condition [42].

$$
\begin{gathered}
\mathrm{Fe}^{+2}+6 \mathrm{CN}^{-} \rightarrow \mathrm{Fe}(\mathrm{CN})_{6}{ }^{4-} \\
\mathrm{Fe}^{+2}+\mathrm{Fe}(\mathrm{CN})_{6}{ }^{4-} \rightarrow \mathrm{Fe}_{2}{ }^{\mathrm{II}} \mathrm{Fe}^{\mathrm{II}}(\mathrm{CN})_{6}(\downarrow) \\
\mathrm{Fe}_{2}{ }^{\mathrm{II}} \mathrm{Fe}^{\mathrm{II}}(\mathrm{CN})_{6} \rightarrow \mathrm{Fe}_{4}{ }^{\mathrm{III}}\left[\mathrm{Fe}^{\mathrm{II}}(\mathrm{CN})_{6}\right]_{3}(\downarrow)+2 \mathrm{Fe}^{+2}+4 \mathrm{e}^{-}
\end{gathered}
$$

349 On the other hand, TOC removal percentage overlaps with theoretical TOC removal percentage during aluminum electrochemical coagulation processes which means an 
351 almost null formation of any soluble cyano aluminum complexes. In addition, a

352 significant influence of the current density is observed. The lower current density applied

353 the higher TOC removal efficiency is attained. Nevertheless, the maximum TOC removal

354 percentage reached is below $40 \%$, regardless of the current density applied.

355 In this context, the mechanisms proposed for free cyanide removal from synthetic mining

356 wastewater by means of both iron and aluminum electrochemical coagulation processes

357 is schematically drawn in Figure 5. It is important to consider that the release of $\mathrm{Fe}^{+2}$ from

358 an iron plate anode leads to the formation of soluble and/or insoluble metal-cyanide

359 complexes during the iron electrochemical coagulation process. The presence of soluble

360 metal-cyanide complexes allows the toxicity of solution to drastically decrease in

361 comparison with the initial toxicity of free cyanide. On the other hand, free cyanide is

362 removed by charge neutralization with soluble $\mathrm{Al}(\mathrm{OH})_{3}$ during the aluminum

363 electrochemical coagulation process. Finally, free cyanide may also be removed thanks

364 to its adsorption on a superficially charged metal precipitate and its enmeshment into a

365 sweep metal floc in both electrochemical coagulation processes. 


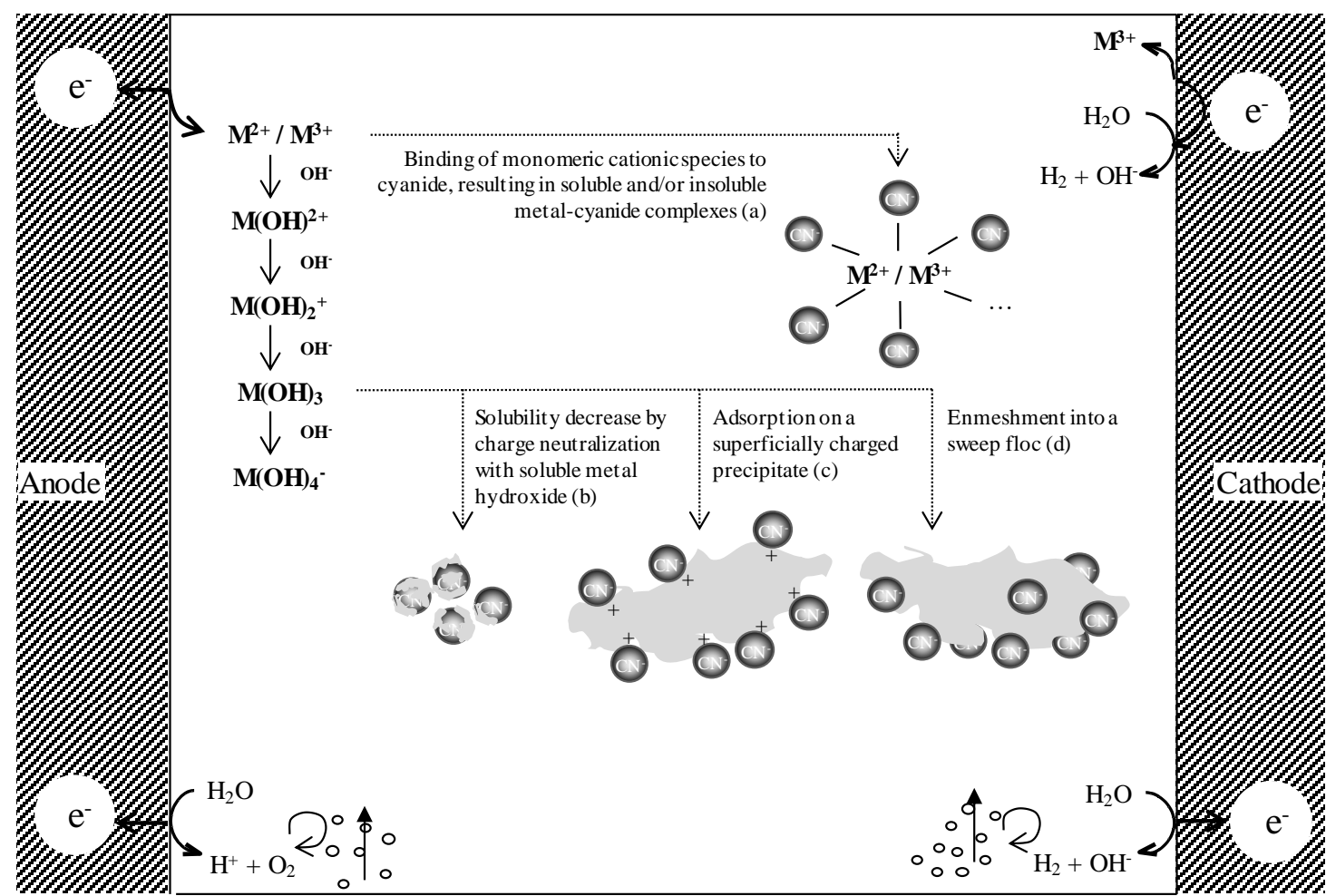

367 Figure 5. Mechanisms proposed for cyanide removal from synthetic mining wastewater

368 during electrochemical coagulation. Anode/Cathode: Fe/Fe (a, c, d), Al/Al (b, c, d).

370 The mechanism proposed for cyanide removal may be supported by the characterization

371 of the sludge generated after the coagulation treatment (shown in Figure 6). The XRD analysis of the resultant sludge from chemical coagulation treatments with $\mathrm{FeCl}_{3}$ (Figure 6a) shows the main diffraction goethite $\left(\mathrm{Fe}^{3+} \mathrm{O}(\mathrm{OH})\right)$ peaks (110), (130), (021), (111), (121), (140), (221), (160), (250) and (061) at $2 \theta=21.1^{\circ}, 33.3^{\circ}, 34.7^{\circ}, 36.6^{\circ}, 39.9^{\circ}, 41.2^{\circ}$, $53.2^{\circ}, 59.1^{\circ}, 61.4^{\circ}$ and $64.1^{\circ}$, respectively. However, the XRD analysis for the sludge generated during electrochemical coagulation with iron electrodes (Figure 6c) confirms

377 not only the presence of the magnetite $\left(\mathrm{Fe}^{2+}\left(\mathrm{Fe}^{3+}\right)_{2} \mathrm{O}_{4}\right)$ peaks (220), (311), (400) (511) and (440) at $2 \theta=30.1^{\circ}, 35.4^{\circ}, 43.0^{\circ}, 57.1^{\circ}$ and $62.7^{\circ}$, respectively, but also the appearance of the ferric ferrocyanide $\left(\mathrm{Fe}_{4}{ }^{\mathrm{III}}\left[\mathrm{Fe}^{\mathrm{II}}(\mathrm{CN})_{6}\right]_{3}\right)$ peak (321) at $2 \theta=28^{\circ}$. This fact could justify 
380 the formation of the cyano iron (II) complexes (Eqs. 10-12) in solution as a significant

381 mechanism to remove free cyanide during electrochemical coagulation with iron

382 electrodes, in comparison to its removal by adsorption onto iron (III) oxide-hydroxide.

383 On the other hand, Figure $6 \mathrm{~b}$ shows a mixture of bayerite $\left(\alpha-\mathrm{Al}(\mathrm{OH})_{3}\right)$ peaks $(001),(101)$,

384 (111) and (112) at $2 \theta=18.7^{\circ}, 27.9^{\circ}, 40.6^{\circ}$ and $53.2^{\circ}$, respectively, and gibbsite $(\gamma-$

$\left.385 \mathrm{Al}(\mathrm{OH})_{3}\right)$ peaks $(110)$ and $(023)$ at $2 \theta=20.3^{\circ}$ and $45.4^{\circ}$ for chemical coagulation with

$386 \mathrm{AlCl}_{3}$. However, only the bayerite $\left(\alpha-\mathrm{Al}(\mathrm{OH})_{3}\right)$ peaks $(001),(101),(111)$ and (112) at $2 \theta$

$387=18.7^{\circ}, 27.9^{\circ}, 40.6^{\circ}$ and $53.2^{\circ}$, respectively, are observed for the electrochemical

388 coagulation with aluminum electrodes in Figure 6d. Here, the difference between gibbsite

389 and its other polymorphs, such as bayerite, consists of a slightly different arrangement of

390 hydroxyl groups which make bayerite more efficient for the removal of free cyanide.
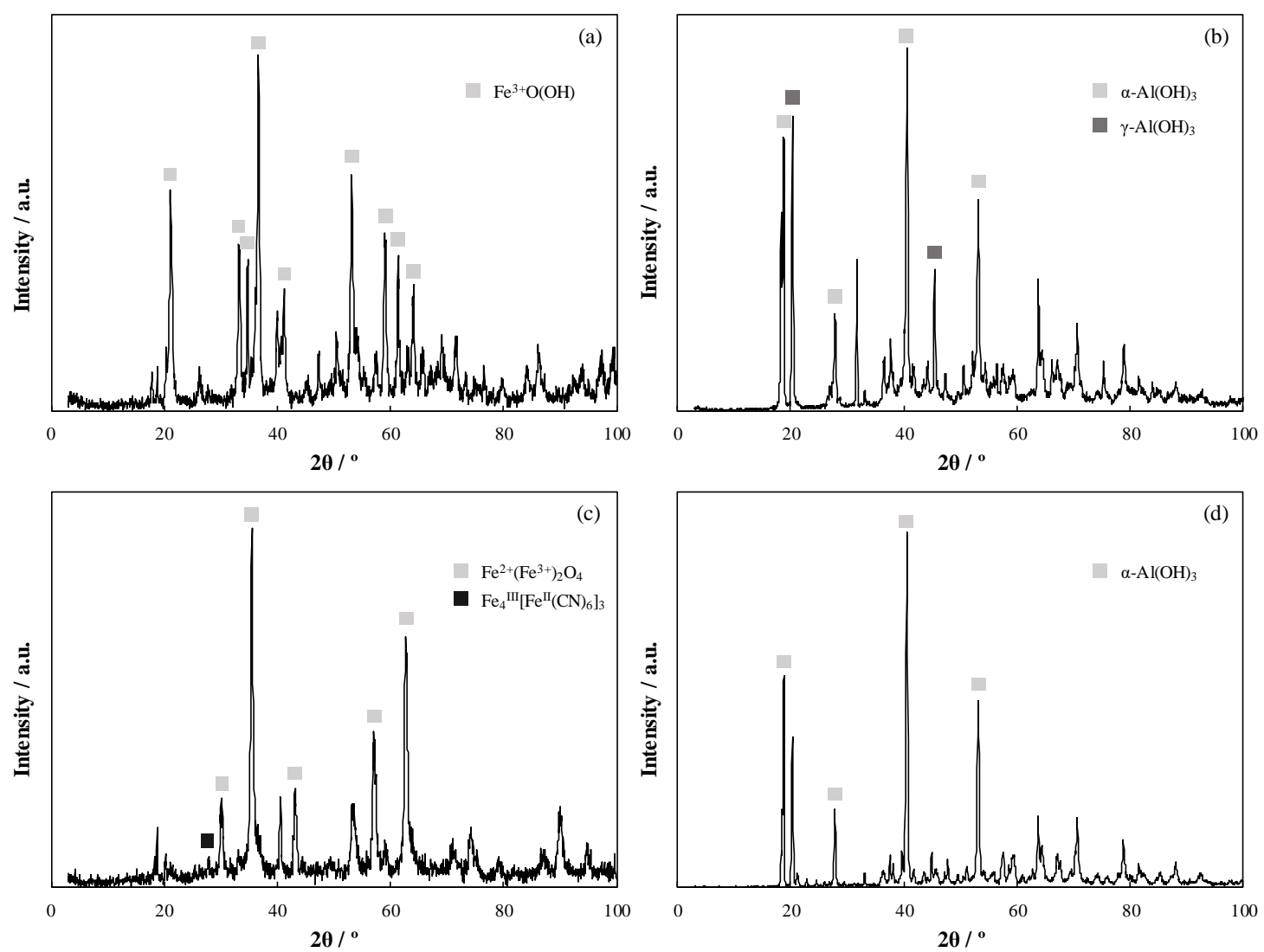
393 Figure 6. XRD analysis of the sludge generated after the coagulation treatment of

394 synthetic mining wastewater intensified with $100 \mathrm{mg} \mathrm{CN}^{-} \mathrm{dm}^{-3}$ : (a) chemical coagulation 395 with $1000 \mathrm{mg} \mathrm{FeCl} \mathrm{dm}^{-3}$, (b) chemical coagulation with $1000 \mathrm{mg} \mathrm{AlCl}_{3} \mathrm{dm}^{-3}$, (c)

396 electrochemical coagulation with $\mathrm{Fe}$ electrodes at $100 \mathrm{~A} \mathrm{~m}^{-2}$, (d) electrochemical 397 coagulation with $\mathrm{Al}$ electrodes at $100 \mathrm{~A} \mathrm{~m}^{-2}$.

399 In order to go more in-depth, the chemical and/or electrochemical reactivity has also been 400 studied for the different species involved in mining wastewater $\left(3000 \mathrm{mg} \mathrm{SO}_{4}{ }^{2-} \mathrm{dm}^{-3}, 300\right.$ $401 \mathrm{mg} \mathrm{Cl}^{-} \mathrm{dm}^{-3}, 60 \mathrm{mg} \mathrm{NO}_{3}^{-} \mathrm{dm}^{-3}, 30 \mathrm{mg} \mathrm{NH}_{4}{ }^{+} \mathrm{dm}^{-3}$ and $100 \mathrm{mg} \mathrm{CN}^{-} \mathrm{dm}^{-3}$ ) in order to 402 determine the possible formation of hazardous species.

403 Regardless of the possible oxidation of cyanide to form cyanate $\left(\mathrm{CNO}^{-}\right), \mathrm{CNO}^{-}$has been 404 not detected by ionic chromatography along with any electrochemical coagulation tests. 405 Anyway, $\mathrm{CNO}^{-}$is well known to quickly decompose as shown in Equation 13. Regarding 406 the formation of other hazardous inorganic species, it is especially important to focus on 407 the chlorine species because chloride may be electrooxidized to chlorine (Eq. 14) and 408 thus, it disproportionates to hypochlorite (Eqs. 15-16) or is further oxidized to other 409 chlorine compounds in higher oxidation state, such as chlorate or perchlorate (Eqs. 17410 19) [43]. These high oxidation state chlorine compounds are reported to be hazardous to 411 human health [44, 45]. For this reason, the evolution of chlorine species has been 412 monitored along with iron and aluminum electrochemical coagulation processes as shown 413 in Figure 7a and 7b, respectively. 

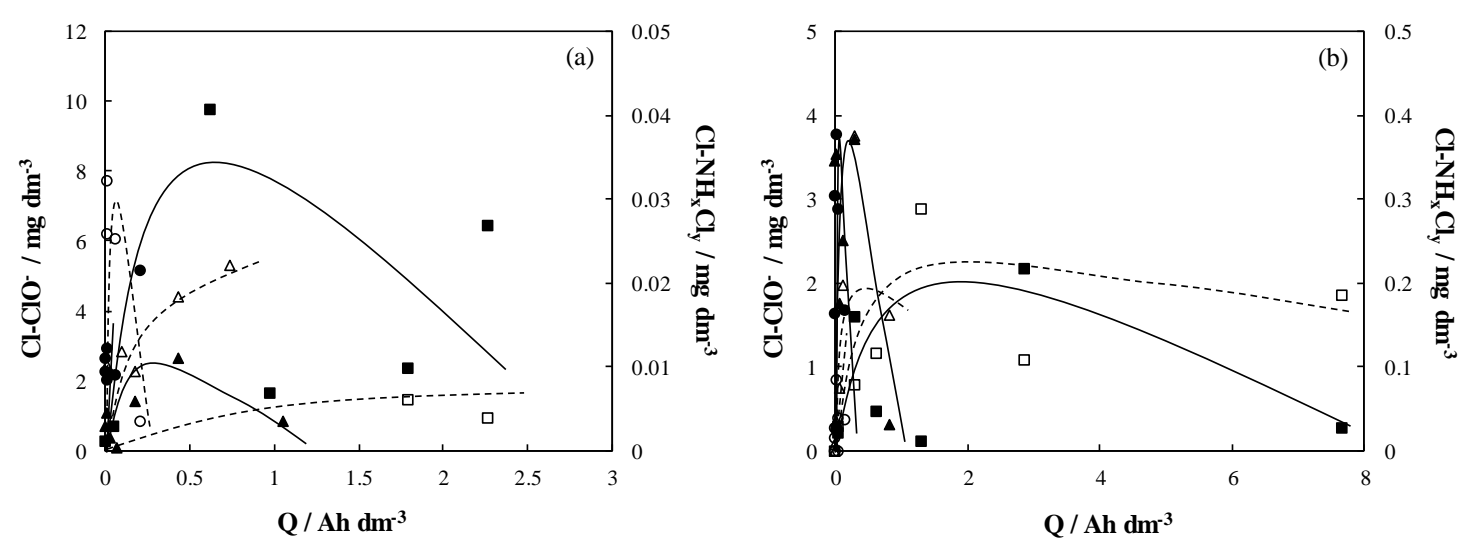

423 Figure 7. Hypochlorite (full symbols) and chloramines (empty symbols) concentrations

424 as a function of applied electric charge during electrochemical coagulation of synthetic

425 mining wastewater intensified with $100 \mathrm{mg} \mathrm{CN}^{-} \mathrm{dm}^{-3}$. Anode/Cathode: $\mathrm{Fe} / \mathrm{Fe}(\mathrm{a}), \mathrm{Al} / \mathrm{Al}$ (b). Current density: $(\bullet) 1 \mathrm{~A} \mathrm{~m}^{-2},(\boldsymbol{\Delta}) 10 \mathrm{~A} \mathrm{~m}^{-2},(\boldsymbol{\bullet}) 100 \mathrm{~A} \mathrm{~m}^{-2}$.

428 Chloride is observed to be transformed into hypochlorite which behaves as a reaction 429 intermediate. The higher the current density applied, the higher is the hypochlorite 430 concentration regardless of iron or aluminum electrochemical coagulation processes. The

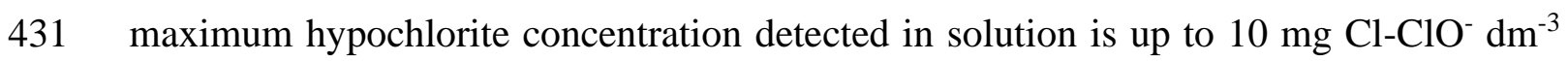




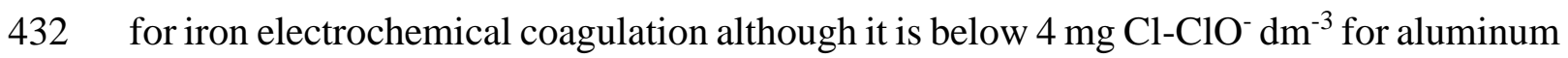

433 electrochemical coagulation. Opposite to it could be expected, hypochlorite does not

434 undergo further oxidation to hazardous chlorine species such as chlorate or perchlorate

435 because these chlorine species have been not detected in solution along with any

436 electrochemical coagulation tests. On the contrary, hypochlorite is well known to

437 chemically react with ammonium ions and then, it results in the production of inorganic

438 chloramines as shown in Equations 20-22 [46, 47].

$$
\mathrm{NH}_{4}^{+}+\mathrm{ClO}^{-} \rightarrow \mathrm{NH}_{2} \mathrm{Cl}+\mathrm{H}_{2} \mathrm{O}
$$

442 As can be observed, the presence of chloramines in solution is influenced by current

443 density applied. The concentration of chloramines ranges from 0.01 to $0.03 \mathrm{mg} \mathrm{dm}^{-3}$

444 during iron electrochemical coagulation and this concentration increases up to 10 times

445 for aluminum electrochemical coagulation. This fact may be explained bearing in mind

446 the chemical reduction of nitrate to ammonium ions by aluminum as shown in Equations

44723 and $24[48,49]$. This confirms the higher concentration of chloramines during

448 aluminum electrochemical coagulation, in comparison with their concentration during

449 iron electrochemical coagulation because of the increase of ammonium ions in solution

450 with aluminum electrodes.

$$
3 \mathrm{NO}_{3}{ }^{-}+2 \mathrm{Al}+3 \mathrm{H}_{2} \mathrm{O} \rightarrow 3 \mathrm{NO}_{2}{ }^{-}+2 \mathrm{Al}(\mathrm{OH})_{3}
$$

$$
\mathrm{NO}_{2}^{-}+2 \mathrm{Al}+5 \mathrm{H}_{2} \mathrm{O} \rightarrow \mathrm{NH}_{3}+2 \mathrm{Al}(\mathrm{OH})_{3}+\mathrm{OH}^{-}
$$


453 Finally, Figure 8 shows the energy consumption as a function of the current density (1-

$454100 \mathrm{~A} \mathrm{~m}^{-2}$ ) for the removal not only of the target organic pollutant cyanide but for the 455 inorganic pollutants presented in mining wastewater such as nitrate, ammonium ions and 456 sulfate during both iron and aluminum electrochemical coagulation processes.
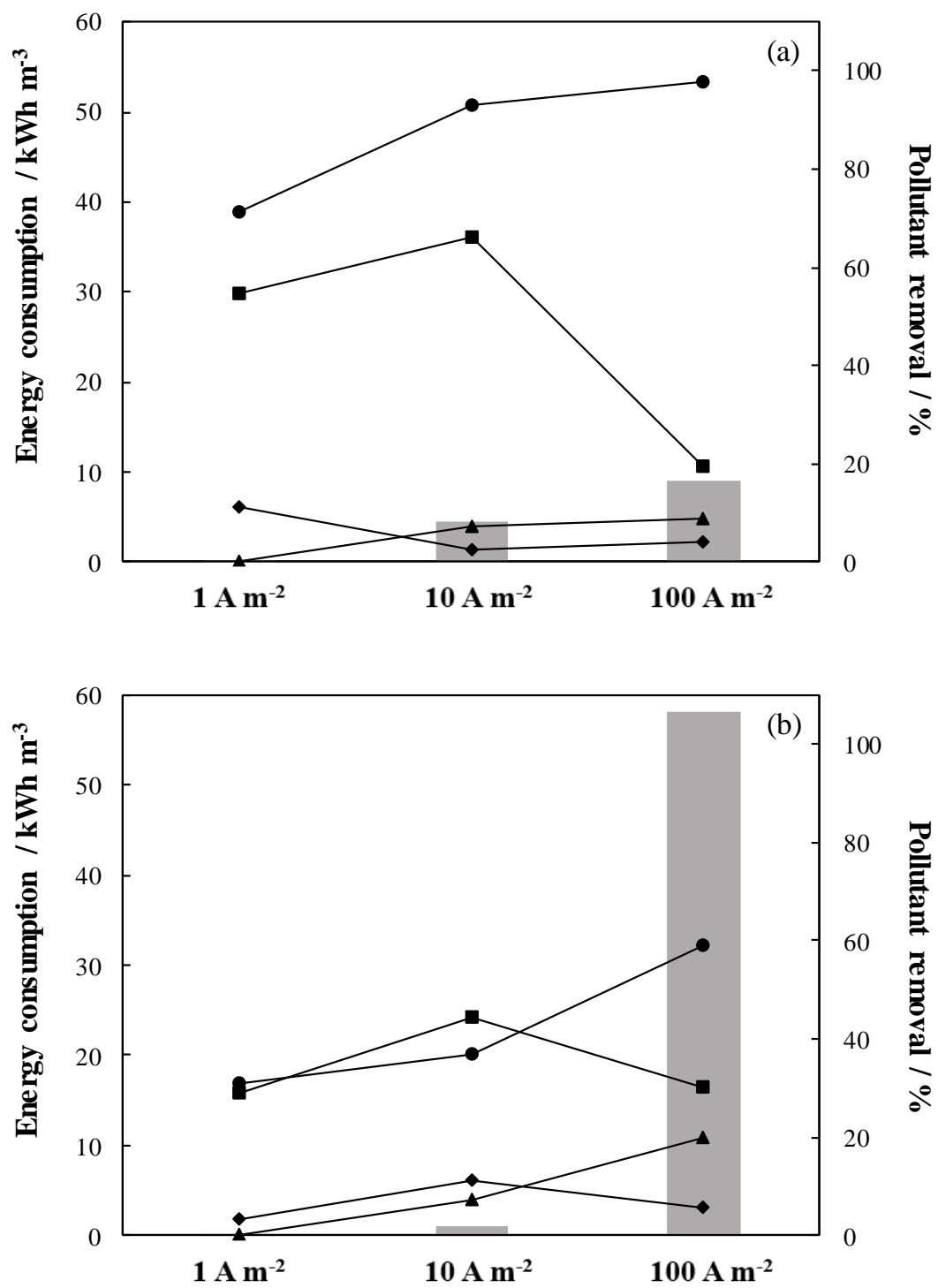

459 Figure 8. Influence of current density on energy consumption (bars) for pollutants 460 removal (points) during electrochemical coagulation of synthetic mining wastewater 
461 intensified with $100 \mathrm{mg} \mathrm{CN}^{-} \mathrm{dm}^{-3}$. Anode/Cathode: $\mathrm{Fe} / \mathrm{Fe}(\mathrm{a}), \mathrm{Al} / \mathrm{Al}$ (b). Pollutant species:

$462(\bullet) \mathrm{CN}^{-},(\boldsymbol{\Delta}) \mathrm{NO}_{3}{ }^{-},(\boldsymbol{\bullet}) \mathrm{NH}_{4}^{+},(\bullet) \mathrm{SO}_{4}{ }^{2-}$.

464 As expected, the energy consumption increases with current density, regardless of the 465 electrode material tested in electrochemical coagulation. However, at the highest current 466 density $10 \mathrm{kWh} \mathrm{m}^{-3}$ are required to remove $100 \%$ of cyanide from mining wastewater 467 during iron electrochemical coagulation, whereas $60 \mathrm{kWh} \mathrm{m}^{-3}$ are only able to attain $60 \%$ 468 of cyanide removal for aluminum electrochemical coagulation. The higher energy 469 consumption with aluminum electrodes may be explained by the higher cell potential needed to electrochemically release the coagulant due to its passivation layer. Likewise, inorganic species from mining wastewater are also removed during both electrochemical coagulation processes although in a much lower range than the target pollutant. Thus, at

$47310 \mathrm{~A} \mathrm{~m}^{-2}$ the removal percentage of nitrates is 7.5 and $7.2 \%$, for ammonium ions is 66.2 and $44.4 \%$ and for sulfates is 2.4 and $11.0 \%$ during iron and aluminum electrochemical coagulation, respectively. The results obtained for the removal of nitrates are in agreement with previous works reported in the literature [49], where the same amount of nitrate removal was obtained for the same reagent dose using both iron and aluminum anodes. Nitrate removal can be explained by adsorption onto growing metal hydroxide precipitates. Moreover, the lower removal of ammonium ions with aluminum electrodes than with iron ones may be explained due to their production by the chemical reaction

481 between nitrates and aluminum which increases their concentration in solution [48].

482 Finally, the removal percentages for sulfates are very low because sulfate may be 483 efficiently removed from mining wastewater by coagulation although at acidic pHs [12]. 


\section{Conclusions}

486 From this work, the following conclusions can be drawn:

487 - Chemical coagulation at $\mathrm{pH}$ of 12 leads to a maximum cyanide removal 488 percentage from mining wastewater of $15 \%$. Although it is not the unique, 489 adsorption onto metal flocs is the primary mechanism that explains results. 490 Experimental data are fitted to Freundlich isotherm with correlation coefficients 491 of 0.7585 for $\mathrm{Fe}-\mathrm{FeCl}_{3}$ and 0.9047 for $\mathrm{Al}-\mathrm{AlCl}_{3}$.

492 - Electrochemical coagulation with iron electrodes leads to the complete cyanide removal from mining wastewater at initial $\mathrm{pH}$ of 12 , regardless of the current density value applied. However, a maximum cyanide removal of $60 \%$ is attained during electrochemical coagulation with aluminum electrodes at the highest current density value tested $\left(100 \mathrm{~A} \mathrm{~m}^{-2}\right)$. The cyanide removal does not fit well to Freundlich isotherm with low correlation coefficients $\left(\mathrm{r}^{2} \mathrm{Fe}=0.1269, \mathrm{r}_{\mathrm{Al}}^{2}=0.1158\right)$ which means that the main coagulation mechanism is not an adsorption process in this case. and/or insoluble iron-cyanide complexes due to the release of $\mathrm{Fe}^{+2}$ from the iron plate anode. In electrochemical coagulation with aluminum electrodes, cyanide decreases its solubility by charge neutralization with aluminum soluble metal hydroxide. Likewise, cyanide may also be removed by adsorption on a superficially charged metal precipitate and enmeshment into a sweep metal floc in both cases.

- Chemical and/or electrochemical reactivity of cyanide and inorganic species from mining wastewater is also studied. A null detection of cyanate or inorganic chlorine hazardous species such as chlorate or perchlorate is found through 
electrochemical coagulation tests. However, chloride oxidizes to hypochlorite and hypochlorite concentrations up to 10 and $4 \mathrm{mg} \mathrm{dm}^{-3}$ are measured for iron and aluminum electrochemical coagulation, respectively. Likewise, hypochlorite behaves as intermediate because it chemically reacts with ammonium ions (contained in mining wastewater or produced by chemical reduction of nitrate by aluminum) to form chloramines in a concentration up to $0.3 \mathrm{mg} \mathrm{dm}^{-3}$ during aluminum electrochemical coagulation.

- The energy consumption required to remove $100 \%$ of cyanide from mining wastewater is $10 \mathrm{kWh} \mathrm{m}^{-3}$ during iron electrochemical coagulation at the highest current density value, whereas $60 \mathrm{kWh} \mathrm{m}^{-3}$ only attains $60 \%$ of cyanide removal along with aluminum electrochemical coagulation. In addition, other inorganic

\section{Acknowledgments}

525 Paula Vehmaanperä is gratefully acknowledged for the development of the analytical

526 method to measure cyanide concentration from aqueous solutions. Financial support from

527 the Spanish Ministry of Economy, Industry and Competitiveness and European Union

528 through project CTM2016-76197-R (AEI/FEDER, UE) and from EIT Raw Materials

529 (European Institute of Innovation and Technology) through project EWT-CYNCOR is

530 gratefully acknowledged. Dr. Salvador Cotillas (SBPLY/16/180501/000404) and Miguel

531 Herraiz-Carboné (SBPLY/18/180501/000009) wish to express their gratitude to the

532 financial support of their grants from Junta de Comunidades de Castilla-La Mancha $533(\mathrm{JCCM})$. 


\section{References}

536 [1] X. Yu, R. Xu, C. Wei, H. Wu, Removal of cyanide compounds from coking

537 wastewater by ferrous sulfate: Improvement of biodegradability, Journal of Hazardous 538 Materials, 302 (2016) 468-474.

539 [2] E. Iakovleva, M. Sillanpää, C. Mangwandi, A.B. Albadarin, P. Maydannik, S. Khan,

540 V. Srivastava, K. Kamwilaisak, S. Wang, Application of Al2O3 modified sulfate tailings

541 (CaFe-Cake and $\mathrm{SuFe}$ ) for efficient removal of cyanide ions from mine process water,

542 Minerals Engineering, 118 (2018) 24-32.

543 [3] N. Kuyucak, A. Akcil, Cyanide and removal options from effluents in gold mining 544 and metallurgical processes, Minerals Engineering, 50-51 (2013) 13-29.

545 [4] J.R. Parga, S.S. Shukla, F.R. Carrillo-Pedroza, Destruction of cyanide waste solutions 546 using chlorine dioxide, ozone and titania sol, Waste Management, 23 (2003) 183-191.

547 [5] T.I. Mudder, M.M. Botz, Cyanide and society: a critical review, European Journal of 548 Mineral Processing \& Environmental Protection, 4 (2004) 62-74.

549 [6] J. Cui, X. Wang, Y. Yuan, X. Guo, X. Gu, L. Jian, Combined ozone oxidation and 550 biological aerated filter processes for treatment of cyanide containing electroplating 551 wastewater, Chemical Engineering Journal, 241 (2014) 184-189.

552 [7] X. Zhao, J. Zhang, J. Qu, Photoelectrocatalytic Oxidation of Cu-cyanides and Cu553 EDTA at $\mathrm{TiO}<\mathrm{inf}>2</ \mathrm{inf}>$ nanotube electrode, Electrochimica Acta, 180 (2015) 129554137.

555 [8] R.R. Dash, C. Balomajumder, A. Kumar, Removal of cyanide from water and 556 wastewater using granular activated carbon, Chemical Engineering Journal, 146 (2009) $557 \quad 408-413$. 
[9] L. Seung-Mok, T. Diwakar, Application of ferrate(VI) in the treatment of industrial

559 wastes containing metal-complexed cyanides: A green treatment, Journal of

560 Environmental Sciences, 21 (2009) 1347-1352.

561 [10] Y. Xu, J. Zhang, Y. Liang, J. Zhou, J. Zhao, X. Ruan, Z.P. Xu, G. Qian, Synchronous

562 cyanide purification with metals removal in the co-treatment of $\mathrm{Zn}-\mathrm{CN}$ and $\mathrm{Ni}$

563 electroplating wastewaters via the Ni2+-assisted precipitation of LDH, Separation and

564 Purification Technology, 145 (2015) 92-97.

565 [11] C.A. Martínez-Huitle, M.A. Rodrigo, I. Sirés, O. Scialdone, Single and Coupled

566 Electrochemical Processes and Reactors for the Abatement of Organic Water Pollutants:

567 A Critical Review, Chemical Reviews, 115 (2015) 13362-13407.

568 [12] M.A. Mamelkina, S. Cotillas, E. Lacasa, C. Sáez, R. Tuunila, M. Sillanpää, A.

569 Häkkinen, M.A. Rodrigo, Removal of sulfate from mining waters by electrocoagulation,

570 Separation and Purification Technology, 182 (2017) 87-93.

571 [13] S. Cotillas, E. Lacasa, M. Herraiz, C. Sáez, P. Cañizares, M.A. Rodrigo, The Role

572 of the Anode Material in Selective Penicillin G Oxidation in Urine, ChemElectroChem,

$5736(2019) 1376-1384$.

574 [14] Z. Ye, E. Brillas, F. Centellas, P.L. Cabot, I. Sirés, Electrochemical treatment of 575 butylated hydroxyanisole: Electrocoagulation versus advanced oxidation, Separation and 576 Purification Technology, 208 (2019) 19-26.

577 [15] S. Cotillas, M.J.M. de Vidales, J. Llanos, C. Sáez, P. Cañizares, M.A. Rodrigo, 578 Electrolytic and electro-irradiated processes with diamond anodes for the oxidation of 579 persistent pollutants and disinfection of urban treated wastewater, Journal of Hazardous $580 \quad$ Materials, 319 (2016) 93-101. 

integrated electrodisinfection/electrocoagulation process with Al bipolar electrodes for urban wastewater reclamation, Water Research, 47 (2013) 1741-1750. powered BDD electrochemical oxidation process for the removal of herbicides, Journal of Environmental Management, 158 (2015) 36-39.

587 [18] M. Millán, M.A. Rodrigo, C.M. Fernández-Marchante, S. Díaz-Abad, M.C. Peláez, P. Cañizares, J. Lobato, Towards the sustainable powering of the electrocoagulation of wastewater through the use of solar-vanadium redox flow battery: A first approach, 590 Electrochimica Acta, 270 (2018) 14-21.

591 [19] F.L. Souza, C. Saéz, J. Llanos, M.R.V. Lanza, P. Cañizares, M.A. Rodrigo, Solar592 powered electrokinetic remediation for the treatment of soil polluted with the herbicide 2,4-D, Electrochimica Acta, 190 (2016) 371-377. [20] S.O. Ganiyu, L.R.D. Brito, E.C.T. de Araújo Costa, E.V. dos Santos, C.A. MartínezHuitle, Solar photovoltaic-battery system as a green energy for driven electrochemical wastewater treatment technologies: Application to elimination of Brilliant Blue FCF dye solution, Journal of Environmental Chemical Engineering, 7 (2019) 102924. [21] P. Cañizares, M. Díaz, J.A. Domíguez, J. Lobato, M.A. Rodrigo, Electrochemical treatment of diluted cyanide aqueous wastes, Journal of Chemical Technology and 600 Biotechnology, 80 (2005) 565-573.

601 [22] M.R.V. Lanza, R. Bertazzoli, Selection of a commercial anode oxide coating for 602 electro-oxidation of cyanide, Journal of the Brazilian Chemical Society, 13 (2002) 345603 351.

604 [23] S.C. Cheng, M. Gattrell, T. Guena, B. MacDougall, The electrochemical oxidation 605 of alkaline copper cyanide solutions, Electrochimica Acta, 47 (2002) 3245-3256. 
606 [24] C. Antonio Pineda Arellano, S.S. Martínez, Indirect electrochemical oxidation of

607 cyanide by hydrogen peroxide generated at a carbon cathode, International Journal of 608 Hydrogen Energy, 32 (2007) 3163-3169.

609 [25] S. Pulkka, M. Martikainen, A. Bhatnagar, M. Sillanpää, Electrochemical methods 610 for the removal of anionic contaminants from water - A review, Separation and 611 Purification Technology, 132 (2014) 252-271.

612 [26] G. Moussavi, F. Majidi, M. Farzadkia, The influence of operational parameters on 613 elimination of cyanide from wastewater using the electrocoagulation process, 614 Desalination, 280 (2011) 127-133.

615 [27] G. Hassani, S. Nasseri, H. Gharibi, Removal of cyanide by electrocoagulation 616 process, Analytical and Bioanalytical Electrochemistry, 3 (2011) 625-634.

617 [28] P. Cañizares, F. Martínez, J. Lobato, M.A. Rodrigo, Electrochemically assisted 618 coagulation of wastes polluted with eriochrome black T, Industrial and Engineering 619 Chemistry Research, 45 (2006) 3474-3480.

620 [29] E. Lacasa, P. Cañizares, C. Sáez, F.J. Fernández, M.A. Rodrigo, Electrochemical 621 phosphates removal using iron and aluminium electrodes, Chemical Engineering Journal, $622172(2011) 137-143$.

623 [30] J.A. Ryan, G.W. Culshaw, The use of p-dimethylaminobenzylidene rhodanine as an 624 indicator for the volumetric determination of cyanides, Analyst, 69 (1944) 370-371.

625 [31] A.v. Wilpert, Über die Analyse von Hypochlorit und Chlorit in einer Lösung, Z. 626 Anal. Chem., 155 (1957) 378-378.

627 [32] H. Freytag, Zur Bestimmung von Hypochlorit, Chlorid und Chlorat in Chlorkalk, Z. 628 Anal. Chem., 171 (1959) 458-458. 
629 [33] P. Cañizares, C. Jiménez, F. Martínez, M.A. Rodrigo, C. Sáez, The pH as a key

630 parameter in the choice between coagulation and electrocoagulation for the treatment of

631 wastewaters, Journal of Hazardous Materials, 163 (2009) 158-164.

632 [34] M. Tyagi, A. Rana, S. Kumari, S. Jagadevan, Adsorptive removal of cyanide from

633 coke oven wastewater onto zero-valent iron: Optimization through response surface

634 methodology, isotherm and kinetic studies, Journal of Cleaner Production, 178 (2018)

$635 \quad 398-407$.

636 [35] A. Samiee Beyragh, M. Varsei, M. Meshkini, A. Khodadadi Darban, E. Gholami,

637 Kinetics and Adsorption Isotherms Study of Cyanide Removal from Gold Processing 638 Wastewater Using Natural and Impregnated Zeolites, Iranian Journal of Chemistry and 639 Chemical Engineering (IJCCE), 37 (2018) 139-149.

640 [36] N. Dwivedi, C. Balomajumder, P. Mondal, Comparative investigation on the 641 removal of cyanide from aqueous solution using two different bioadsorbents, Water 642 Resources and Industry, 15 (2016) 28-40.

643 [37] H.J. El-Aila, K.M. Elsousy, K.A. Hartany, Kinetics, equilibrium, and isotherm of the 644 adsorption of cyanide by MDFSD, Arabian Journal of Chemistry, 9 (2016) S198-S203.

645 [38] P. Cañizares, F. Martínez, C. Jiménez, J. Lobato, M.A. Rodrigo, Comparison of the 646 aluminum speciation in chemical and electrochemical dosing processes, Industrial and 647 Engineering Chemistry Research, 45 (2006) 8749-8756.

648 [39] P. Cañizares, F. Martínez, C. Jiménez, J. Lobato, M.A. Rodrigo, Coagulation and 649 electrocoagulation of wastes polluted with dyes, Environmental Science and Technology, $65040(2006) 6418-6424$.

651 [40] C. Racaud, K. Groenen Serrano, A. Savall, Voltammetric determination of the 652 critical micellar concentration of surfactants by using a boron doped diamond anode, 653 Journal of Applied Electrochemistry, 40 (2010) 1845-1851. 
654 [41] X. Yu, R. Xu, C. Wei, H. Wu, Removal of cyanide compounds from coking 655 wastewater by ferrous sulfate: Improvement of biodegradability, J Hazard Mater, 302 656 (2016) 468-474.

657 [42] P. Kjeldsen, Behaviour of cyanides in soil and groundwater: A review, Water, Air, 658 and Soil Pollution, 115 (1999) 279-307.

659 [43] A. Sánchez-Carretero, C. Sáez, P. Cañizares, M.A. Rodrigo, Electrochemical 660 production of perchlorates using conductive diamond electrolyses, Chemical Engineering 661 Journal, 166 (2011) 710-714.

662 [44] Y. Kurokawa, T. Imazawa, M. Matsushima, N. Takamura, Y. Hayashi, Lack of 663 Promoting Effect of Sodium Chlorate and Potassium Chlorate in Two-Stage Rat Renal 664 Carcinogenesis, Journal of the American College of Toxicology, 4 (1985) 331-337.

665 [45] J.R. Lubbers, S. Chauan, J.R. Bianchine, Controlled clinical evaluations of chlorine 666 dioxide, chlorite and chlorate in man, Environmental health perspectives, 46 (1982) 5766762.

668 [46] E. Lacasa, J. Llanos, P. Cañizares, M.A. Rodrigo, Electrochemical denitrificacion 669 with chlorides using DSA and BDD anodes, Chemical Engineering Journal, 184 (2012) $670 \quad 66-71$.

671 [47] S. Cotillas, J. Llanos, K. Castro-Ríos, G. Taborda-Ocampo, M.A. Rodrigo, P. 672 Cañizares, Synergistic integration of sonochemical and electrochemical disinfection with 673 DSA anodes, Chemosphere, 163 (2016) 562-568.

674 [48] A.P. Murphy, Chemical removal of nitrate from water, Nature, 350 (1991) 223-225. 675 [49] E. Lacasa, P. Cañizares, C. Sáez, F.J. Fernández, M.A. Rodrigo, Removal of nitrates 676 from groundwater by electrocoagulation, Chemical Engineering Journal, 171 (2011) $677 \quad 1012-1017$.

678 